\title{
Meaningful Work Scale in creative industries: a confirmatory factor analysis
}

\author{
Pedro F. Bendassolli - Universidade Federal do Rio Grande do Norte, Natal, Brasil \\ Jairo Eduardo Borges-Andrade - Universidade de Brasilia, Brasilia, Brasil \\ Joatã Soares Coelho Alves - Universidade Federal do Rio Grande do Norte, Natal, Brasil \\ Tatiana de Lucena Torres - Universidade Federal do Rio Grande do Norte, Natal, Brasil
}

\begin{abstract}
This study conducts a confirmatory factor analysis of a meaningful Canadian work model. The sample comprised 446 professionals working in creative industries based in Midwestern and Northeastern Brazil who completed the 25-item Meaningful Work Scale (MWS). This study tested both the original Canadian five-factor model and a six-factor model previously adapted into Portuguese, based on professionals from São Paulo's creative industries. The results indicate that globally, both models, when re-specified, seem to fit the data. However, an inspection of the local fit indices suggests problems with both models, specifically in two factors: development and learning, and expressiveness and identification with work. We discuss the extent to which these findings may relate to cultural and occupational influences. The paper concludes that the meaningful work model, although it can vary in content, is vulnerable to possible subculture differences in the Brazilian context.

Keywords: work; meaning; employee attitudes.
\end{abstract}

\section{Escala do Trabalho com Sentido nas indústrias criativas: análise fatorial confirmatória}

\begin{abstract}
Resumo
O objetivo deste artigo é realizar uma análise fatorial confirmatória de um modelo canadense de trabalho com sentido. Participaram desta pesquisa 446 profissionais das indústrias criativas das regiões centro-oeste e nordeste do Brasil. Esses participantes responderam à Escala do Trabalho com Sentido (ETS), composta por 25 itens. Foram testados tanto o modelo original canadense de cinco fatores como o de seis fatores previamente validado para o contexto brasileiro. Os resultados indicam que, globalmente, os dois modelos reespecificados apresentam evidências de adequação. Porém, a inspeção do ajuste local revela problemas em ambos, particularmente em relação a dois fatores: desenvolvimento e aprendizagem, e expressividade e identificação no trabalho. Discute-se em que medida esses achados podem estar associados a influências culturais e ocupacionais. Conclui-se que o constructo do trabalho com sentido, embora possa variar em conteúdo, resiste a possíveis diferenças de subculturas no contexto brasileiro.
\end{abstract}

Palavras-chave: trabalho; significado; atitudes do empregado.

Escala de Trabajo con sentido en las industrias creativas: un análisis factorial confirmatorio

\begin{abstract}
Resumen
Este artículo realiza un análisis factorial confirmatorio de un modelo canadiense de Trabajo con Sentido. Participaron 446 profesionales de las industrias creativas de la región centro-oeste y nordeste de Brasil. Esos participantes respondieron a la Escala de Trabajo con Sentido (ETS) compuesta por 25 ítems. Se experimentó el modelo original canadiense de cinco factores, así como el de seis factores previamente validado para el contexto brasileño. Los resultados indicaron que, globalmente, ambos modelos re-especificados presentan evidencias de adecuación. Sin embargo, la inspección del ajuste local revela problemas en los dos modelos, particularmente en relación a dos factores: desarrollo y aprendizaje, y expresividad e identificación en el trabajo. Se discute en qué medida estos hallazgos pueden estar asociados a influencias culturales y ocupacionales. Se concluye que el constructo de trabajo con sentido, aunque pueda variar en contenido, resiste a posibles diferencias de subculturas en el contexto brasileño.

Palabras-clave: trabajo; significado; actitud del empleado.
\end{abstract}

The seminal research conducted by the Meaning of Work (MOW) Research Team (1987) is commonly cited as an important milestone in the systematization of studies about the meaning of work (e.g., Bendassolli, Alves, \& Torres, 2014; Borges, 1998; Mourão \& BorgesAndrade, 2001; Tolfo \& Piccinini, 2007). Indeed, the MOW research team introduced important conceptual elements to define and operationalize the meaning of work construct in terms of its psychological signification: "the significance, beliefs, definitions and the value which individuals and groups attach to working as a major stream of human activity" (p. 13). The MOW team conceived this model in order to develop and measure groups of variables associated with the meaning of work, in terms of either antecedents (familiar situation, current job and career background, and macrosocial and economic environment) or consequents (subjective expectations about future working conditions and objective results at work) at the individual, occupational, and societal levels. Another objective of 
the MOW team was to establish working patterns of meaning and their practical implications.

During the past few decades, researchers have largely used the three main dimensions of the MOW (1987) model, which are as follows. The psychological centrality dimension includes identification, (affective) involvement, and commitment with respect to work, along with an absolute or relative centrality of work in one's life. The societal norm dimension concerns rights and duties related to work and corresponds to the key aspects of the distributive justice concept: the right to remuneration and opportunities, and retribution duties to society. Finally, the third dimension of the model, concerning the evaluation of work outcomes, objectives, and functional identification with work, includes the rewards and work contents that predispose an individual to perform the work and that guide the individual's preferences through different working situations. The MOW team's study has influenced researchers in Brazil who have contributed to the model's cultural adaptation and local dissemination (e.g., Bastos, Pinho, \& Costa, 1995; Borges, 1999; Soares, 1992).

As a matter of hypothesis, we can suggest that the MOW (1987) model has contributed to a tendency to measure the meaning of work from an essentially descriptive perspective. This has happened because the MOW model assumes that the construct is compounded from static dimensions that vary over time (Borges, 1998). Furthermore, the research strategy based on antecedents and consequents has led researchers to a tendency to prioritize the analysis of the separate aspects of meaning rather than considering meaning as a whole, that is to say, as a dynamic and complex experience of generating meaningfulness at work. At the extreme, this has led researchers to focus on a mere description of the meanings people attribute to work in the most varied occupations and activities. Our critical analysis is supported by the international literature, in which changes in the ways this phenomenon is understood and researched have been noticeable for decades (as noted, e.g., by Lips-Wiersma \& Wright, 2012; Steger, Dik, \& Duffy, 2012; Van den Heuvel, Demerouti, Schreurs, Bakker, \& Schaufeli, 2009).

One reference point for this change in the research focus is the emergence of positive psychology in organizational studies (e.g., Dik, Byrne, \& Steger, 2013; Pratt \& Ashforth, 2003; Rosso, Dekas, \& Wrzesniewski, 2010). Researchers associated with this approach aim to study the impacts of meaning perception on many aspects of an individual's relation to his or her work, such as well-being (Arnold, Turner, Barling, Kelloway, \& McKee, 2007), satisfaction (Sparks \& Schenk, 2001), motivation (Spreitzer, 1995), engagement (May, Gilson, \& Harter, 2004), sense of identity (Ashforth, 2001), and a deeper feeling that life is meaningful as a whole (Dik \& Steger, 2008). Positive psychology understands meaning as a crucial source for human functioning and development (Batthyany \& Russo-Netzer, 2014).

Positive psychology has given rise to a wide field of studies that make a crucial distinction between the meaning of work and meaningful work. According to Steger, Dik, and Duffy (2012), meaningful work is defined "not as simply whatever work means to people (meaning), but as work that is both significant and positive in valence (meaningfulness)" (p. 2). This kind of significant experience occurs when an individual is able to reflect about the meaning of his or her work based on his or her moral values and life objectives, and not when the individual simply endorses inherited meanings (Van den Heuvel et al., 2009). The individual must be an active agent, a meaning crafter (Wrzesniewski, 2003).

Briefly, research on the meaning of work is spread over a broad spectrum of perspectives: from the most traditionally descriptive perspectives (e.g., MOW, 1987) to others that are closest to existentialist, humanist, and, recently, positive psychology perspectives. According to the existentialist perspective, meaningful work has been reached when someone is capable of experiencing a feeling of completeness and coherence while working (Lips-Wiersma \& Wright, 2012). Many theories have been proposed to measure meaningful work based on these different theoretical influences.

For instance, Lips-Wiersma and Wright (2012) suggested a four-dimension model that includes development of the inner self, unity with others, service to others, and expression of full potential. Steger, Dik, and Duffy (2012) presented a model in which meaningful work is compounded from three dimensions: (a) personal meaningfulness-subjective meaningful experiences regarding what a person is doing (the person's activity), (b) meaning making through work when a person can entirely connect the meaningfulness of his or her work to the meaningfulness of his or her life; and (c) greater good motivations "reflecting ideas that work is most meaningful if it has a broader impact on others" (p. 4). Both of these models are related to validated measures. Nevertheless, they have not yet been translated and adapted to the Brazilian context. 
On the other hand, the model suggested by Morin (1997, 2006, 2007), Morin and Cherré (1999) and Morin and Dassa (2006), also for the meaningful work construct, is widely used in work psychology research in Brazil (e.g., Bendassolli \& Borges-Andrade, 2011, 2013; Morin, Tonelli, \& Pliopas, 2007; Tolfo \& Piccinini, 2007). Morin divides the meaning of work into three dimensions. The first dimension concerns the significance an individual attaches to work, the representations and values the individual attributes to it. The second dimension concerns the individual's orientation, the individual's inclination regarding work, the individual's objective at work, and the plans that guide the individual's actions. The third dimension, which echoes the existentialist influence described above, is related to the coherence or harmony between the individual and his or her work, in such a way that "the meaning of work is an effect from the coherence between the characteristics one pursues and the characteristics he/she identifies at the work he/she does" (Morin (2006), p. 5, authour's translation).

Operationally, Morin (1997, 1999, 2003, 2007) measures the effect of this coherence based on identification of the general characteristics of meaningful work. During her many research studies, which in the beginning were qualitative, Morin identified many sets of such characteristics, which culminated in the development of a specific instrument that we will call the Meaningful Work Scale (MWS). In its first version, it comprised 30 items answered by 582 professionals from health care and welfare services in Québec, which resulted in a six-factor structure: pleasure in work, work utility, work success conditions, autonomy, security, and moral correctness. In a second application, this time with a 35-item version that was answered by 262 employees from a hospital in Québec, Morin obtained eight factors: moral correctness, autonomy, support, work utility, learning, recognition, interpersonal relations, and pleasure in work. More recently, Morin and Dassa (2006) constructed a final version with 25 items and a five-factor empirical structure.

The first factor in the final version, development and learning, concerns the perception of work as corresponding to (coherent with) an individual's interests and competences, or what allows the individual to express him- or herself through work. The model assumes that the mobilization and practice of competences are associated with personal efficacy which, in turn, reinforces personal identity. Learning in work occurs at both a technical level (know-how) and a personal one (the development of an individual's potential). The development and learning factor, as well as the majority of the factors that follow it, is associated with job enrichment theory (Hackman \& Oldham, 1976) and sociotechnical theory (Ketchum \& Trist, 1992).

The second factor, work utility, concerns the pragmatic aspects of work, which is viewed as an activity through which something new is produced that can help society. This factor is tantamount to the "expected and valued results of work" factor in the MOW (1987) model. Morin (2007) points out that this factor is related to the benefits of the work for the common good. The third factor, quality of working relationships, concerns the interpersonal dimension of work, including perceptions of cooperation in the workplace, solidarity among workers, and social support. This source of meaning is widely reported in the literature (e.g., Rosso et al., 2010).

The fourth factor, autonomy, is related to the possibilities for the individual to make his or her own judgements and exercise his or her creativity as well as to the individual's liberty in performing work activities. Meaningful work according to this factor presupposes that an individual can organize his or her tasks, in particular, in a way that he or she considers to be more effective. Finally, the fifth factor, moral correctness, concerns the perception that the work an individual performs corresponds to the ideals valued in the individual's society and that it is realized in a socially responsible fashion.

In Brazil, the first (and still the only) research using MWS was conducted by Bendassolli and BorgesAndrade (2011) with professionals from creative industries, sectors that are focused on the production of goods and services with an immaterial and cultural content (Wood, Bendassolli, Kirschbaum, \& Pina e Cunha, 2009). Adopting an exploratory methodology, Bendassolli and Borges-Andrade found differences from the factorial model suggested by Morin and Dassa (2006), with regard to the latter's development and learning factor. The differences can be explained by the fact that they used a sample of professionals working in a very specific sector, one where the expressive aspects of work are highly valued.

Therefore, considering the importance of expanding investigations of meaningful work, and particularly because most of the current studies in Brazil are on the meaning of work (following the MOW's stream), the main purpose of this paper is to determine whether the six-factor structure suggested by Bendassolli and Borges-Andrade (2011), which may possibly be specific 
to the type of worker who participated in their investigation (artists) and to certain aspects of Brazilian culture (their sample of artists came from São Paulo), can also be found in a new sample with participants from the same professional field but from other regions of Brazil. We conducted this study with three guiding questions that we expected to answer through a confirmatory method.

The three guiding questions are: (1) Retaining the same professional category but with participants from different regional contexts (the Brazilian midwest and northeast), would we confirm the six-factor structure? (2) If so (or if not), could the new findings point to a national subcultural influence on the meaning of work construct and, at the same time, to an occupational invariance - both of which have already been described in the literature, for example, by the MOW (1987) team itself? Finally, (3) at which level should Morin's model be analyzed, considering the criticisms made by Lips-Wiersma and Wright (2012) and Steger, Dik, and Duffy (2012), and reviewed in our introduction, that many research models for the meaning of work tend to emphasize its antecedents and consequents, along with its descriptive dimensions, rather than elaborating on the very phenomenon of meaningfulness?

\section{Method}

\section{Participants}

A total of 446 professionals working in creative industries sectors from midwestern (nearly 20\%) and northeastern (around 80\%) regions of Brazil participated in this study. This number is the final questionnaire contingent that was effectively used. In the sample, $44,8 \%$ were men. The average age was 29,69 years $(D P=10,69)$, and the oldest participants were 67 years old. Most professionals were from the dance and theater sectors (49\%) and the music sector (36\%). There were also some professionals from the plastic arts sector $(8,5 \%)$, the literature sector $(3,5 \%)$, and the design and illustration sector $(3,0 \%)$. The length of time participants had worked in these sectors varied from 1 to 50 years, with a average of 11,66 years of work $(D P=8,87)$. Among the participants, $54,9 \%$ were working in two careers (that is to say, in two lines of work), with $45,3 \%$ of the second careers not related to creative/artistic work. Confirming an already known reality in this area (Menger, 1999), 90\% of the workers did not have formal jobs. Thus, they were individual and autonomous entrepreneurs. Most of the participants $(62,5 \%)$ stated that they performed their work activities regularly, without any interruption longer than 30 days.

\section{Instrument}

We used the MWS as our data-gathering instrument, with the items rated through a scale similar to a six-point Likert scale. As described in the introduction, this instrument was developed by Morin and Dassa (2006) and suggests a five-factor structure for measuring meaningful work (Figure 1). It was adapted by Bendassolli and Borges-Andrade (2011), who obtained six factors (Figure 2). Four factors are common to both the original and the adapted models (in parentheses: Cronbach's alpha for the original version and the Brazilian adapted version, respectively): quality of working relationships $(0,85 ; 0,81)$; work utility $(0,84 ; 0,92)$; autonomy $(0,77 ; 0,89)$; and moral correctness $(0,90$; $0,91)$. The difference between the original model and the adapted model relates to the first factor in Figure 1, namely, learning and development (0,89 Cronbach's alpha). In the Brazilian research, this factor was divided into two factors, both of which contain four items each (Figure 2): development and learning (0,87 Cronbach's alpha; Factor 4), and expressiveness and identification at work (0,76 Cronbach's alpha; Factor 6).

\section{Data-gathering procedures}

The strategies we used to access the potential participants were based on the same procedures used by Brazilian researchers who are also interested in this public (e.g., Bendassolli \& Borges-Andrade, 2011, 2013). We compiled a potential participant contact base, with information gathered from trade union, artistic group, and working class agency websites, online portfolios, discussion forums, and curriculum data pages. Through this procedure, we obtained nearly 1,000 possible participants' e-mail addresses.

We used two data-gathering strategies: one online and the other face-to-face. In the first case, we sent an e-mail invitation to the potential parcipants identified in the previously described contact base to join the research, along with the website link to the virtual version of the questionnaire. When answers to these first virtual invitations stopped arriving, we began to propagate the research through social media. This strategy consisted of accessing professional creative groups from all states in northeast and midwest Brazil, presenting the research in common areas in the social media and in private messages sent directly to the artists' 
profiles. Although we considered this to be an efficient strategy for increasing the number of responses to the online questionnaire, there came a point in time when we no longer received online answers. This is when we began face-to-face administration of the questionnaire.

We conducted the face-to-face administration in academic spaces (technical course and arts specialization course classrooms) and at artistic events, cultural presentations, discussion groups, round tables, class meetings, and academic meetings. First, we asked for authorization from those responsible for these spaces, explaining the goals of the research and the logistic/ operational aspects involved. After authorization was granted, we personally approached potential participants, presenting the research and the ethics of the procedures involved and inviting them to answer the questionnaire, if they wished to. Finally, a reserved and, as far as possible, disturbance-free area was chosen so that the participants could calmly indicate their answers.

In order to keep the conditions similar to the virtual application conditions, there was no interference from the researchers (for example, explaining answers or providing information about the instrument). Nevertheless, in order to study possible differences related to the data-gathering strategies, we performed a $t$-test (for independent samples) at $p<0,01$, comparing the answers from the online format and the face-toface format. Of the 25 questions in the instrument, only two showed significant differences $\left(t_{(468)}=3,17\right.$; $\left.t_{(469)}=2,77\right)$. However, we decided to retain these in our analysis because we understood that this result could be related to the sample characteristics and not to the data-gathering format itself. Additionally, we considered this decision to be supported by the fact that 23 questions ( $92 \%$ of the questionnaire) did not present any differences with respect to the presentation format.

Of all the questionnaires that were properly filled out, $37 \%$ came from the online presentation format, while the largest number of answers was obtained through the face-to-face strategy (63\%). The entire process, not only the virtual presentation but the personal presentation as well, was done respecting Resolution 196/96 from the National Health Council (Conselho Nacional de Saúde; CNS) - including the filling out and signing of the Informed Consent Form.

\section{Data analysis procedures}

We screened the data in order to identify possible normality violations, multicollinearity, and extreme multi- and univaried cases. The distribution presented some negative and leptokurtic asymmetry. Taking into account the kurtosis and asymmetry values found in the variables, which varied, respectively, from $|-0,03|$ to $|5,13|$ and from $|-0,36|$ to $|2,09|$, and comparing them to the criteria presented by Kline $(2011 ;|K u|<$ 10 and $|S k|<3$ ), we found no problems concerning the normality that would prevent the analysis from being carried out. We excluded twelve extreme, serious, univaried cases (cases that had $z$-scores $\geq 3,29$ ), and six extreme, multivaried cases (based on Mahalanobis's square distance, with $p<0,01)$.

We tested the models in Figures 1 and 2 (M1 and M2) with the support of the AMOS 20 analysis software. To verify the global adjustment quality of the model, we used the fit indices presented in Table 1. Conversely, to rate the local adjustment quality of the model, we considered the following items: factorial validity (standardized factorial weight $\geq|0,50|$ ), item reliability $\left(R^{2} \geq 0,25\right)$, and latent scale item reliability: Cronbach's alpha $(\alpha \geq 0,70)$ and composed reliability $(\mathrm{CR} \geq 0,70)$. We also analyzed the convergent validity by the average variance extracted (AVE $\geq 0,50$ ) and the discriminant validity (square root of $\mathrm{AVE} \geq r$ from the correlations between the factor pairs). We adopted the maximum likelihood method.

\section{Results}

Table 1 presents the global adjustment indices of the two models. Both of the models presented fragile adjustment indices. In order to improve these results, we submitted the models to respecification processes based, as reference, on theoretical considerations and the modification indices suggested by AMOS. As can also be seen in Table 1, after these respecifications, both models began presenting good and very similar fits to the data. Only slight differences between the parsimony indicators of the two respecified models (according to the AIC/CAIC criterion) were identified. Figures 1 and 2 present the estimates for both models $(p<0,001)$.

Although the two models were individually and independently respecified, some modeling decisions were common, which brings our attention to important aspects of the MWS that need to be highlighted. First, in both cases, items Q18 ("I work in an environment which respects people") and Q3 ("My work allows me to have good relations with my colleagues") were eliminated. Item Q18 was loaded in all factors, both in M1 (Figure 1) and in M2 (Figure 2). 
Table 1. Adjustment Indices of the Models Tested: Five-Factor Model (M1) and Six-Factor Model (M2)

\begin{tabular}{lcccc}
\hline \multirow{2}{*}{ Contents } & \multicolumn{2}{c}{ M1 } & M2 \\
\cline { 2 - 5 }$\chi^{2}$ & Original & Respecified & 789,233 & Respecified \\
gl & 911,537 & 464,807 & 237 & 467,994 \\
$\chi^{2 / d f}$ & 265 & 177 & 3,330 & 192 \\
GFI & 3,440 & 2,626 & 0,866 & 2,437 \\
TLI & 0,855 & 0,909 & 0,880 & 0,910 \\
CFI & 0,868 & 0,920 & 0,897 & 0,930 \\
AIC & 0,883 & 0,939 & 915,233 & 0,942 \\
CAIC & 1031,537 & 572,807 & 1236,553 & 589,994 \\
RMSEA & 1337,556 & 847,224 & 0,072 & 900,426 \\
\hline
\end{tabular}

Note. Estimated parameters under $p<0,001$. The reference values (Byrne, 2010; Marôco, 2010) were: GFI, TLI, and CFI $\geq 0,90$; RMSEA $\leq 0,05 ; \chi^{2 / d f} \sim 1 ; \chi^{2}=$ the lower, the better. AIC/CAIC $=$ the lower, the better.

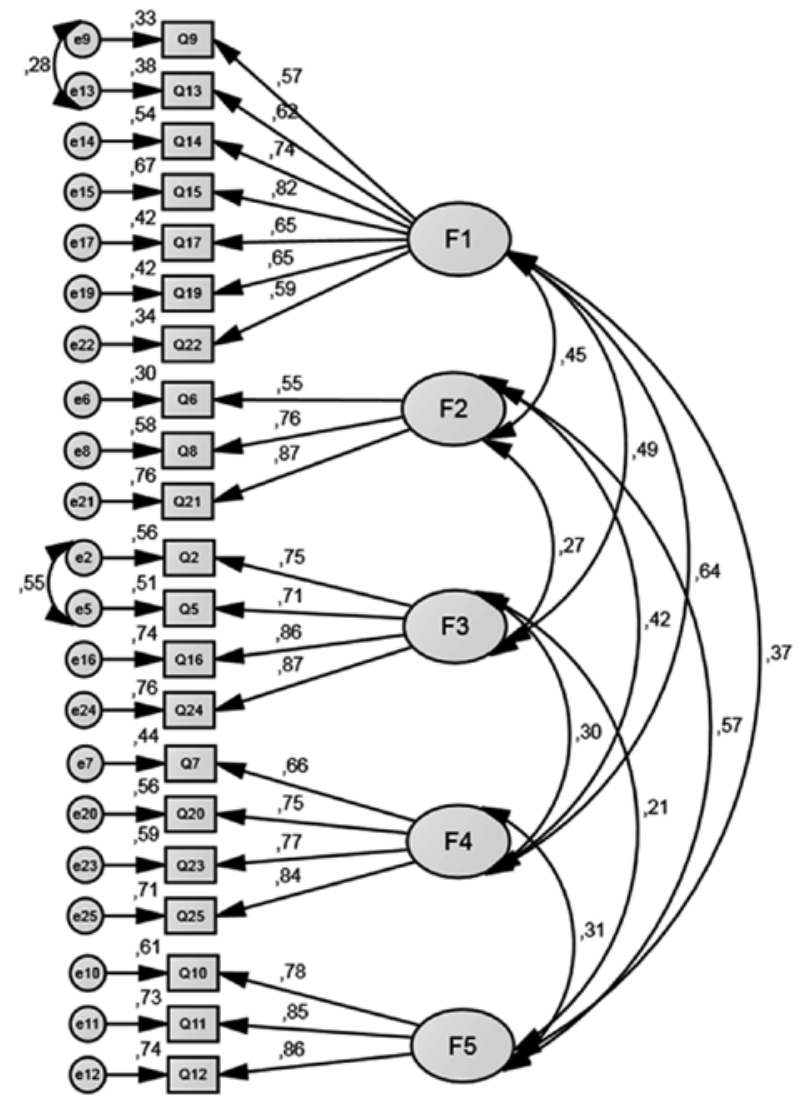

Figure 1. Result of the confirmatory analysis estimates for respecified model 1 (M1R).

Note. F1=Learning and development; F2=quality of working relationships; $\mathrm{F}=$ work utility; $\mathrm{F} 4=$ autonomy; $\mathrm{F} 5=$ moral correctness. Source: Morin \& Dassa (2006).

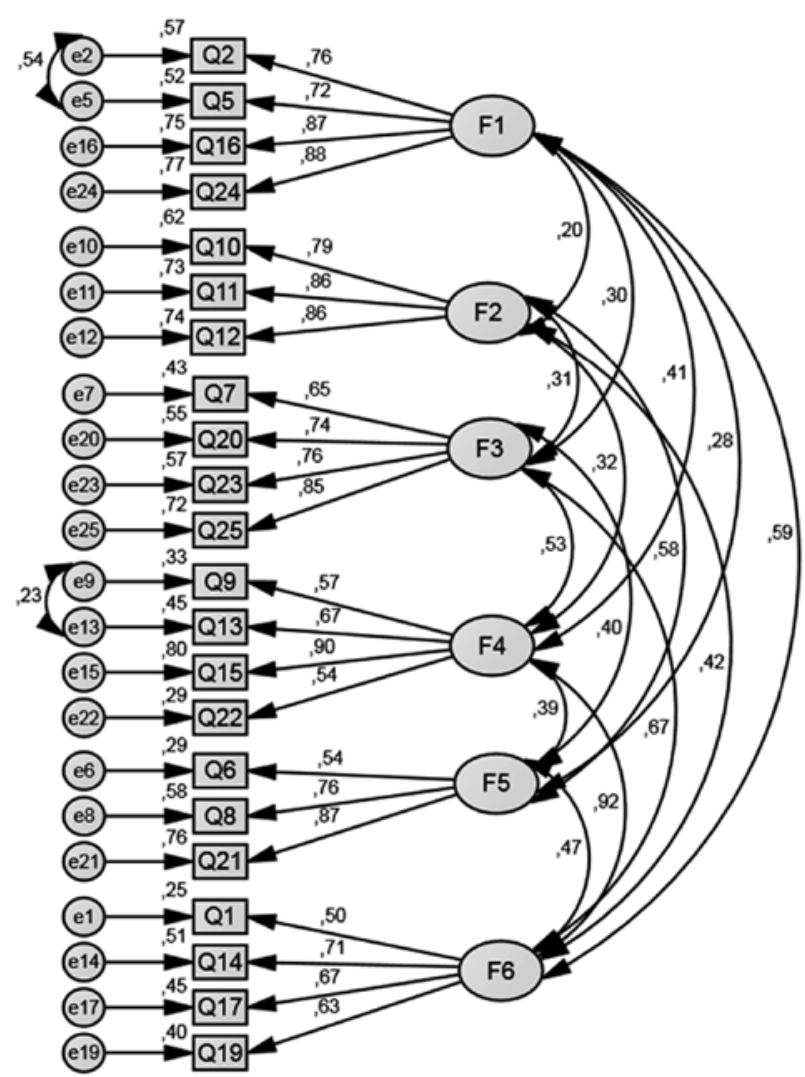

Figure 2. Result of the confirmatory analysis estimates for respecified model 2 (M2R).

Note. F1=work utility; F2=moral correctness; F3=autonomy; $\mathrm{F} 4=$ development and learning; F5=quality of working relationships; F6=expressiveness and identification at work. Source: Bendassolli and Borges-Andrade (2011), Morin and Dassa (2006). 
Item Q3 showed a lower factorial loading $(|0,43|)$, and its error was correlated to the error in item Q6 ("I have good relations with my job mates"). This fact is probably due to the semantic proximity between these two items.

Second, another common decision was the addition of a trajectory between the errors of items Q2 ("My job is useful to society") and Q5 ("My job brings contributions to society"), and between the errors of items Q9 ("My job allows me to develop") and Q13 ("My job allows me to learn"). Once more, it seems there is some formulation or content similarity between these items, which makes them redundant.

However, other respecification strategies were carried out only for M1. In this case, two other items were excluded based on a conservative inspection of their factorial loadings. These were item Q1 $(|0,49|$; "I work on something that corresponds to my competences") and item Q4 (|0,46|; "My work gives me much satisfaction"). This latter item (Q4) had also been excluded in the validation research done by Bendassolli and Borges-Andrade (2011). As expected, the error of this item was correlated to the error of item Q22 ("I feel pleasure in doing my work"). Even though this last item (Q22) has been retained in the model, it is necessary to keep in mind that it evaluates an aspect of meaningful work (satisfaction) that seems to be some distance from other aspects in the model (learning, utility, moral correctness).

Concerning the evaluation of local consistency (Table 2), we can see that the indices (Cronbach's alpha) of both models vary from 0,72 to 0,89 , which can be considered satisfactory and good, respectively. For the composite reliability (CR), the situation is similar: the indices vary from 0,72 to 0,88 in both models.
Based on the scores in Table 2, it is also possible to affirm that the instrument, even in the 25 -item five-factor version and the 22 -item six-factor version, provides evidence of convergent validity, with the AVE varying from 0,42 to 0,69 . Such validity occurs when the items that are reflections of a factor load stronger at this factor-which means that the item's behavior is basically explained by this factor. Specifically, two factors present values slightly under the minimum criterion (which is 0,50$)$ : Factor 1 in M1R $(0,46)$ and Factor 6 in M2R $(0,42)$.

Bendassolli and Borges-Andrade (2011) explained the division of the original Factor 1 (Figure 1) in terms of the importance that this kind of professional attributes to the expressive aspects of his or her work. Aspects such as the possibility of making oneself heard and expressing oneself through work would not necessarily be associated with learning and development, but they would compound a specific factor: Factor 6 (M2R). This interpretation also seems to apply in the present research, at least partially, because the fact that the reliability indicator (AVE) for Factor 1 (MR1) was slightly less than the minimum criterion may suggest that the answers to this factor's items are not completely explained by the perception of learning and development in work. However, and paradoxically, M2R's Factor 6 also presents a lower indicator concerning convergent validity $(0,42)$.

The discriminant validity indicators (Table 2) point to another important characteristic of Factors 4 and 6 . In the confirmatory factor analysis, discriminant validity indicates whether the items that reflect a factor are not correlated to other factors, which means that the factors are distinct from one another. In this regard, apparently not by chance, only M2R presents

Table 2. Reliability and Validity Indices of the Respecified Model Factors

\begin{tabular}{lcccccc}
\hline \multirow{2}{*}{ Factor } & \multicolumn{2}{c}{$\alpha$} & \multicolumn{2}{c}{ CR } & \multicolumn{2}{c}{ AVE } \\
\cline { 2 - 7 } & M1R & M2R & M1R & M2R & M1R & M2R \\
\hline F1 & 0,83 & 0,89 & 0,84 & 0,88 & $0,44(0,66)$ & $0,65(0,80)$ \\
F2 & 0,77 & 0,77 & 0,77 & 0,87 & $0,54(0,73)$ & $0,69(0,83)$ \\
F3 & 0,89 & 0,89 & 0,87 & 0,83 & $0,64(0,80)$ & $0,58(0,76)$ \\
F4 & 0,83 & 0,83 & 0,84 & 0,77 & $0,57(0,75)$ & $0,49(0,70)$ \\
F5 & 0,87 & 0,87 & 0,87 & 0,77 & $0,69(0,83)$ & $0,60(0,77)$ \\
F6 & - & 0,72 & - & 0,72 & - & $0,42(0,64)$ \\
\hline
\end{tabular}

Note. $\alpha=$ Cronbach's alpha; $C R=$ composed reliability; $\mathrm{AVE}=$ average variance extracted. In parentheses, the AVE's square root. 
some problems. The problems occur exactly with the factors derived from M1R's Factor 1, as previously discussed. Both Factor 4 (development and learning) and Factor 6 (expressiveness and identification at work) present lower values for the AVE's square root $(0,70$ and 0,64 , respectively) than the correlation between $\mathrm{F} 4$ and F6 $(r=0,92)$. At first sight, this could point to some inadequacy in the original Factor 1's (Figure 1) division into two factors in M2R (Figure 2), leading us to the five-factor model option. Nevertheless, as has just been discussed, Factor 1's original model itself also presented a lower result than expected in the discriminant validity indicator. In the next section, we discuss the findings based on the reference literature and on the questions that guided this study.

\section{Discussion}

This research aimed to determine whether the six-factor structure identified by Bendassolli and Borges-Andrade (2011), related to the meaningful work model proposed by Canadian researchers Morin and Dassa (2006), would be confirmed with a new sample of creative industries professionals, this time originating from Brazilian regions other than than the Brazilian region represented in the 2011 study-and if so, whether this confirmation would be influenced by cultural and/or occupational aspects of the participants. The results presented above indicate that, from a general point of view (the construct point of view), the meaningful work model is consistent, because structurally, most of the factors were confirmed, revealing that the theoretical domain of the construct is similar to that expected in the original theory (Morin, 1997, 2003, 2007).

The differences between the five- and six-factor structures are limited to the dimension quantity and do not raise any questions about the model's structural validity. If the latter were the case, the adjustment indices would indicate that the data are not adequately explained by the theoretical model. Our conclusion that the differences are limited to dimension quality can be explained in terms of a distinction between the construct level (meaning level) and the content level (construct empirical manifestation)—see, for example, Bendassolli, Alves, and Torres (2014) and Osigweh (1989). Therefore, the results of this research, despite the eventual preference for the five- or six-factorial structure, seem not to contest the theoretical domain of Morin (1997, 2003, 2007) and Morin and Dassa
(2006). This is a positive result, because it suggests evidence of the validity of the theoretical model under investigation.

Having presented these general considerations, we now recast the guiding questions of the study. Regarding the first question, whether retaining the same professional category would confirm the six-factor structure, the results are ambiguous. First, the original Factor 1 produced a convergent validity indicator slightly below expectations. This indicates that there may be internal problems concerning the factor, in the sense that its items cannot be properly explained by the factor. Second, Factors 4 and 6 of the model adapted by Bendassolli and Borges-Andrade (2011) also presented some problems - in this case, in terms of discriminant validity: the results suggest that the two factors evaluate similar facets of the meaning of work.

These results may be interpreted from several perspectives. For example, in reports on her research that demonstrated the five-factor structure, Morin (2003, 2006) presented alternative versions in which learning and development sometimes combine as a single unique factor but sometimes are separated. When they are separated, Morin associates the development of competences with satisfaction, positing cause-effect relations between them, as presented in this quote: "The use of know-how and the exercise of abilities foster satisfaction in doing the requested work" (Morin (2006) p. 30, author's translation). Based on this idea, either the five-factor version or the six-factor version seems plausible at first.

However, the theoretical characteristics that permeate the construction of the instrument may help explain the lower consistency of Factor 1's original model. The author herself (Morin, 2006) and Morin and Dassa (2006) seem to admit items that consider, in a single factor, learning, development of competencies, pleasure/satisfaction, and reaching goals. From a psychometric point of view, this may be responsible for items that are explained not by the referenced factor (development and learning), but by another factor that was not foreseen. Thinking of future possibilities, a suggestion that emerges in this respect is to review the formulation and integration of the original Factor 1 and to explore the possibility of second-order factors in the model.

Nevertheless, the fact is that the results obtained in this research confirm five of six possible factors of meaningful work with a sample that belongs to the same professional category as Bendassolli and 
Borges-Andrade's (2011) study but originates from other regions of the country (possible cultural variations). These results lead us to the second guiding question of this study, concerning the influence of culture and occupation on the meaning of work. First, it is important to emphasize that this construct has been discussed from transcultural and transoccupational perspectives (e.g., Brief \& Nord, 1990; England, 1990; Harpaz \& Fu, 1997; Kuchinke, Ardichvili, Borchert, \& Rozanski, 2009; Ruiz-Quintanilla \& Wilpert, 1991) since the seminal research of MOW (1987). It is fairly well established that the meaning of work, in empirical terms (not in terms of the construct, as previously discussed), is influenced by culture and by the specific work activities. In Brazil, this fact has already been pointed out by other authors who have developed models of the meaning of work adapted to the Brazilian context, but still based on MOW (e.g., Bastos, et al., 1995; Bendassolli et al., 2014; Borges, 1999; Soares, 1992).

In the present study, the option of a five-factor model would be based on parsimony criteria and also on the proximity of the five-factor model to the original model based on Canadian workers in occupational categories different than the ones studied here (Morin, 1997, 2003, 2006). In addition, the results point to some discriminant convergence issues between Factors 4 and 6 in the respecified model, which, at first, counted against the division of the original Factor 1 (although the construct as a whole would be consistent).

Although this research does not have a methodological design that permits the establishment of factorial invariance, which is necessary for comparing means between different cultural/subcultural groups (Milfont \& Fischer, 2000), the five-factor confirmation seems to reinforce, in an exploratory approach, the generality of the model suggested by Morin. All other things being equal (occupation, for example), one can say, as a hypothesis, that Morin's model may reflect the main characteristics that define meaningful work, despite subcultural influences.

Finally, the proximity between the adjustment indicators of the two models also says something about the role of the activity. Since the present study involved participants in activities similar to those of the participants in Bendassolli and Borges-Andrade's (2011) study, why did this sample of professionals from midwestern and northeastern Brazil not unambiguously confirm the six-factor structure? One reason may be related to the sample composition. It is possible, for example, that the participants in the current sample might be closer, in terms of working values and representations, to a work culture associated much more with traditional economic activities than to a creative culture - something that has already been suggested by other studies with artists (e.g., Bendassolli \& Borges-Andrade, 2013; Menger, 2002, 2009). The valorization of expressiveness as a single factor may be related to the socialization in artistic culture, which has been pointed out to be a culture marked by particular orientations regarding work, occupation, work-life balance, and preferences (e.g., Chateau, 2008; Menger, 1999, 2009). Possibly, the reference group in the present study was not so close to this genre or artistic culture as the participants in Bendassolli and Borges-Andrade's study.

The third and last guiding question concerns analyzing the meaningful work model suggested by Morin $(1997,2003,2006)$ with respect to criticisms that such a model might tend to emphasize the descriptive dimensions of meaningful work (LipsWiersma \& Wright, 2012) and its antecedents and consequences rather than examining the construct itself and the dynamic and subjective processes of meaning production. Once more, answering this question depends on acknowledging the limitations of this research. Although the results allow some conjectures concerning the topic, our answers in this paper are not exhaustive but should encourage further research in the future.

It is particularly remarkable that items measuring satisfaction and pleasure at work were theorized as associated with learning and development by Morin (2006) and Morin and Dassa (2006). It is highly probable that this association had some influence on the lower reliability indicator of this factor. In addition, although Morin $(1997,2006)$ had argued that meaningful work is work in which people feel satisfied, from a psychometric point of view, the factor loadings of these items were either low or insufficient for retaining them in the model. This raises some theoretical questions about the model, especially concerning what is probably its most dubious dimension: development and learning.

The above reflections on the three questions were conditioned by several aspects of the choices made in this research. First, this research does not present a specific methodology to clearly determine cultural differences. Also, in this research, we consider cultural influence simply in terms of the participants coming from geographic regions that are distinct from the 
ones used in Bendassolli and Borges-Andrade's (2011) research. Further investigations could explore other ways to understand the influence of culture on the meaning of work. This would reinforce the inter- and transcultural tradition from which this area emerged, in addition to contributing to a larger explanation of the interaction between cultural elements and meaning production - not only in the consideration of meaning, but also in the consideration of meaningfulness.

A second aspect relates to the sample composition. Since the sample was based on voluntary adhesion (convenience), there is no detailed information about the participants' characteristics, particularly concerning the activities they perform in the creative industries sector. As already mentioned, this fact may have contributed to the ambiguity related to the original model's Factor 1 and to Factors 4 and 6 in the respecified model.

Finally, new research could be conducted using MWS to study worker populations from traditional sectors of the economy. This will enable more homogeneous comparison conditions once the instrument is idealized for this public. There also remains the challenge of developing research that takes as a reference models of meaningful work other than the ones suggested in this article. We think it is time to go beyond MOW (1987).

\section{References}

Arnold, K. A., Turner, N., Barling, J., Kelloway, E. K., \& McKee, M. C. (2007). Transformational leadership and psychological well-being. Journal of Occupational Health Psychology, 12, 193-203.

Ashforth, B. E. (2001). Role transitions in organizational life. Mahwah, NJ: Erlbaum.

Bastos, A. V. B., Pinho, A. P. M., \& Costa, C. A. (1995). Significado do trabalho. Revista de Administração de Empresas, 35(6), 20-29.

Batthyany, A., \& Russo-Netzer, P. (2014). Meaning in positive and existential psychology. New York, NY: Springer.

Bendassolli, P. F., Alves, J. S. C., \& Torres, C. C. (2014). Inventário sobre significado do trabalho de profissionais de indústrias criativas. Avaliação Psicológica, 13(2), 177-186.

Bendassolli, P. F., \& Borges-Andrade, J. E. (2011). Significado do trabalho nas indústrias criativas.
RAE-Revista de Administração de Empresas, 51(2), 143-159.

Bendassolli, P. F., \& Borges-Andrade, J. E. (2013). Meaningfulness in work in Brazilian and French creative industries. The Spanish Journal of Psychology, 16, 1-15.

Borges, L. O. (1998). Os pressupostos dos estudos do significado do trabalho na psicologia social: A caminho do existencialismo. Vivência, 12(2), 87-105.

Borges, L. O. (1999). A estrutura fatorial dos atributos valorativos e descritivos do trabalho. Estudos de Psicologia, 4(1), 107-139.

Brief, A. P., \& Nord, W. R. (Eds.). (1990). Meanings of occupational work. Lexington, MA: Lexington Books.

Byrne, B. M. (2010). Structural equation modeling with AMOS: Basic concepts, applications, and programming. New York, NY: Routledge, Taylor \& Francis.

Chateau, D. (2008). Qu'est-ce qu'un artiste? Rennes: Presses Universitaires de Rennes.

Dik, B. J., Byrne, Z. S., \& Steger, M. (2013). Purpose and meaning in the workplace. Washington, DC: American Psychological Association.

Dik, B. J., \& Steger, M. F. (2008). Randomized trial of a calling-infused career workshop incorporating counselor self-disclosure. Journal of Vocational Behavior, 73, 203-211.

England, G. W., \& Harpaz, I. (1990). How working is defined. Journal of Organizational Behavior, 11(4), 253-266.

Hackman, J. R., \& Oldham, G. R. (1976). Motivation through the design of work: Test of a theory. Organizational Behavior and Human Performance, 16, 250-279.

Harpaz, I., \& Fu, X. (1997). Work centrality in Germany, Israel, Japan, and the United States. Cross-Cultural Research, 31(3), 171-200.

Ketchum, L. D., \& Trist, E. (1992). All teams are not created equal. London, England: Sage.

Kline, R. B. (2011). Principles and practice of structural equation modelling. New York, NY: Guilford Press.

Kuchinke, K. P., Ardichvili, A., Borchert, M., \& Rozanski, A. (2009). The meaning of working among professional employees in Germany, Poland and 
Russia. Journal of European Industrial Training, 33(2), 104--124.

Lips-Wiersma, M., \& Wright, S. (2012). Measuring the meaning of meaningful work. Group \& Organization Management, 37, 655-685.

Marôco, J. (2010). Análise de equações estruturais. Pêro Pinheiro, Portugal: ReportNumber.

May, D. R., Gilson, R. L., \& Harter, L. M. (2004). The psychological conditions of meaningfulness, safety and availability and the engagement of the human spirit at work. Journal of Occupational and Organizational Psychology, 77, 11-37.

Meaning of Work Research Team [MOW]. (1987). The meaning of working. San Diego, CA: Academic Press.

Menger, P. M. (1999). Artistic labor markets and careers. Annual Review of Sociology, 25, 541-574.

Menger, P. M. (2002). Portrait de l'artiste en travailleur. Paris, France: Seuil.

Menger, P. M. (2009). Le travail créateur. Paris, France: Seuil.

Milfont, T. L., \& Fischer, R. (2000). Testing measurement invariance across groups. International Journal of Psychology, 3(1), 111-121.

Morin, E. (1997). Le sens du travail pour des gestionnaires francophones. Revue Psychologie du Travail e des Organizations, 3(2/3), 26-45.

Morin, E. (2003). Sens du travail: Définition, mesure et validation. In C. Vandenberghe, C. N. Delobbe, \& G. Karnas (Eds.), Dimensions individuelles et sociales de l'investissement professionnel (pp. 11-20). Louvain la Neuve, Belgium: UCL.

Morin, E. (2006). Donner un sens au travail. Montréal, Quebec, Canada: HEC.

Morin, E. (2007). Sens du travail, santé mentale au travail et engagement organisationnel. Cabier de Recherche, 543, 99-193.

Morin, E., Tonelli, M. J., \& Pliopas, A. L. V. (2007). O trabalho e seus sentidos. Psicologia \& Sociedade, 19(número especial), 47-56.

Morin, E. M., \& Cherré, B. (1999). Les cadres face au sens du travail. Revue Française de Gestion, 126, 83-93.Morin, E. M., \& Dassa, C. (2006). Characteristics of a meaningful work. Montréal, Quebec, Canada: HEC.
Mourão, L., \& Borges-Andrade, J. E. (2001). Significado do trabalho: Caminhos percorridos e sinalização de tendências. Revista de Estudos Organizacionais, 2(2), 59-76.

Osigweh, C. A. B. (1989). Concept fallibility in organizational science. The Academy of Management Review, 14(4), 579-594.

Pratt, M. G., \& Ashforth, B. E. (2003). Fostering meaningfulness in working and at work. In K. S. Cameron, J. E. Dutton, \& R. E. Quinn (Eds.), Positive organizational scholarship (pp. 309-327). San Francisco, CA: Berrett-Koehler.

Rosso, B. D., Dekas, K. H., \& Wrzesniewski, A. (2010). On the meaning of work: A theoretical integration and review. Research in Organizational Behavior, 30, 91-127.

Ruiz-Quintanilla, S. A., \& Wilpert, B. (1991). Are work meanings changing? European Work and Organizational Psychologist, 1(2-3), 91-109.

Soares, C. R. V. (1992). Significado do trabalho: Um estudo comparativo de categorias ocupacionais (Dissertação de mestrado não publicada). Universidade de Brasília, Brasília, Brazil.

Sparks, J. R., \& Schenk, J. A. (2001). Explaining the effects of transformational leadership. Journal of Organizational Behavior, 22, 849-869.

Spreitzer, G. (1995). Psychological empowerment in the work place. Academy of Management Journal, 38, 1442-1465.

Steger, M. F., Dik, B. J., \& Duffy, R. D. (2012). Measuring meaningful work: The work and meaning inventory. Journal of Career Assessment, 20(3), 322-337.

Tolfo, S. R., \& Piccinini, V. (2007). Sentidos e significados do trabalho explorando conceitos, variáveis e estudos empíricos brasileiros. Psicologia \& Sociedade, 19(edição especial), 38-46.

Van den Heuvel, M., Demerouti, E., Schreurs, B. H. J., Bakker, A. B., \& Schaufeli, W. B. (2009). Does meaning-making help during organizational change? Career Development International, 14, 508-533.

Wood Jr., T., Bendassolli, P. F., Kirschbaum, C., \& Pina e Cunha, M. (2009). Indústrias criativas: Definição, limites e possibilidades. Revista de Administração de Empresas, 49(1), 10-18. 
Wrzesniewski, A. (2003) Finding positive meaning in Recebido em: 14/03/2014 work. In K. S. Cameron, J. E. Dutton, \& R. E. Quinn (Eds.), Positive organizational scholarship (pp. 296-308). San Francisco, CA: Berrett-Koehler.

Primeira Reformulação em: 20/11/2014

Aprovado em: 10/12/2014

Sobre os autores:

Pedro F. Bendassolli é doutor em Psicologia Social do Trabalho (USP) e professor do departamento de Psicologia da UFRN. E-mail: pbendassolli@gmail.com. Site: http://www.pedrobendassolli.com

Jairo Eduardo Borges-Andrade é Ph.D em sistemas instrucionais pela Florida State University e professor do departamento de Psicologia Social e do Trabalho no Instituto de Psicologia da UnB. E-mail: jairo.borges@gmail.com

Joatã Soares Coelho Alves é mestrando do programa de pós-graduação do departamento de Psicologia da UFRN. E-mail: joatasoares@gmail.com

Tatiana de Lucena Torres é doutora em Psicologia Social (UFSC) e professora do departamento de Psicologia da UFRN. E-mail: tltorres2@gmail.com

Contato com os autores:

Departamento de Psicologia, Centro de Ciências Humanas Letras e Artes

Universidade Federal do Rio Grande do Norte

Av. Senador Salgado Filho, s/n, Campus Universitário, Lagoa Nova

Natal, RN, Brasil

CEP: 59078-970 